\title{
The Depth of Pressure Source and Magma Supply Volume for Merapi Eruption during 2009-2011 Using the Combination of Yokoyama and Mogi Model
}

\author{
Andi Athiyah Anshariyah', Abdul Basid ${ }^{2}$ \\ ${ }^{1,2}$ Department of Physics, Faculty of Science and Technology, Universitas Islam Negeri \\ Maulana Malik Ibrahim Malang, Indonesia. 65144 \\ \{athiyahanshariyah@gmail.com¹, faizabasid@yahoo.co.id²\}
}

\begin{abstract}
Merapi Volcano is an active stratovolcano located on the border between Central Java and Yogyakarta Province, Indonesia. A VEI (Volcano Explosively Index) IV eruption of Merapi began on 26th october 2010. This research aims to estimate the depth of pressure source and magma supply volume during 2009 - 2011. There are eight GPS stations installed around merapi volcano. During the eruption in October 2010, GPS data have shown lengthening of the baselines between Merapi's crater and monitoring stations, it means that merapi has already entered into inflation process. Merapi Volcano begins to deflate in 2011. Estimation of the depth of pressure source and magma supply volume has been done using Mogi and Yokoyama models. The result shown the depth of pressure source before eruption is around $2.3 \mathrm{~km}$ and the magma supply volume about 55 million $\mathrm{m} 3$.
\end{abstract}

Keywords: Merapi volcano, GPS survey, Volcano modelling.

\section{Introduction}

Vulcanology is a study of volcanoes, magma, eruption, or even the volcanoes' deformation. Vulcanology is extremely crucial to be learned or to be applied in human's life. Indonesia sits in the Pacific ring of fire. The ring of fire is major area in basin of the Pacific Ocean where many earthquakes and volcanic eruption occur. One of many active volcanoes in Indonesia is Merapi volcano. It is located at the border between central Java and Yogyakarta Province [1].

There are many negative impacts of Merapi's eruption in 2010. Around 200 people passed away and 14 villages damaged. According to [2] around 10\% of Indonesia people live in the area endangered by the volcanic eruptions, and about 3 million of them live in the danger zones. This fact alone suggests that in Indonesia the monitoring of volcano activity should be performed not only routinely but should also be done as good as possible [3].

The latest research about magma storage and the estimation of the depth of pressure source in Merapi Volcano has been done by Beauducel and Cornet in 1999 [4]. They are using GPS and tiltmeter as their method. The average displacement that recorded by 6 GPS sensors are about 6 to $6.5 \mathrm{~cm}$. The depth of pressure source is $8.5 \mathrm{~km}$ below the summit of Merapi and the magma storage inside Merapi is about 11 million $\mathrm{m}^{3}$. Parameters in this research refers to this 
Beauducel's research. The radius of magma pouch is $550 \mathrm{~m}$, rigidity of medium is $2 \times 10^{10} \mathrm{~Pa}$, and the change of hydrostatic pressure is $10^{5} \mathrm{~Pa}$.

After a huge eruption of Merapi in 2010, there are so many aspects of Merapi volcano were changed. Before eruption, it's 2968 meters high. But after the eruption, it is 2930 meters high (38 meters lower than before). It is called volcano deformation. Volcano deformation delivers informations about the changes of volcano's surface related to volcanic activities which is caused by the migration of magma inside the volcano [5].

This research uses GPS (Global Positioning system) as its method. GPS is system of satellites, computers and receivers that is able to determine the latitude and longitude of a receiver on earth by calculating the time difference for signal from different satellites to reach the receiver [6]. GPS is such a very effective method to use to monitor the deformation because location of GPS point perfectly spread and illustrate the whole shape of the volcano. Besides, GPS data is the most accurate method among the others. This research aims to specify the deformation, to estimate the magma supply volume, and the depth of pressure source of Merapi volcano during the eruption 2010 .

\section{Material and Methods}

\subsection{Merapi Volcano}

Merapi volcano is one of many active sratovolcano in Indonesia. In its activities, Merapi can endanger people and environvment around it [7]. Merapi volcano is located in Central Java and included into one of the most active volcano in Java. Merapi volcano sits in $7^{\circ} 32.5^{\prime} \mathrm{S}, 110^{\circ}$ $26.5^{\prime}$ E. It is 2953,244 meters high.

In late October 2010, the center of volcanology and Geological Hazard mitigation. Geological Agency (Pusat Vulkanologi dan Mitigasi Bencana Geologi PVMBG) reported that a pattern of increasing seismicity from Merapi had begun to emerge in early September, official said about 500 volcanic earthquakes had been recorded on the mountain over the weekend of 23-24 October 2010, and the magma had risen about 1 kilometer below the surface due to the seismic activity [8].

\subsection{Volcano Deformation}

Volcano deformation is the change of shape, position, and dimension of volcanoes. Volcano deformation delivers informations about the changes of volcano's surface related to volcanic activities which is caused by the magma's migration inside volcano [9].

Volcano deformation is divided into two parts, they are inflation and deflation, inflation occurs because magma flows up to the upper ground. Inflation in GPS data is shown by the baseline lengthening. Deflation occurs after the eruption. After eruption occurs, magma's pressure ran down and slowly go back to its previous position [10].

\subsection{Mogi Model}

A Mogi source is often referred to in a general science to describe a burned spherical source which undergoes either a pressure change or a volume change. The development of Mogi model 
has considered 3D topography effect and magma pouch effect (nonspherical and nonaxisymmetrical) [11].

$\mathrm{U}_{\mathrm{r}}$ is radial movement vector and $\mathrm{U}_{\mathrm{z}}$ is vertical movement vector. Below is the scheme of Mogi model and coordinate change that has been recorded by GPS sensor [12]:

$$
U_{r}=\frac{(1-v) \alpha^{3} \Delta P}{G}\left[\frac{r}{\left(f^{2}+r^{2}\right)^{3 / 2}}\right]
$$

(1)

$$
U_{z}=\frac{(1-v) a^{3} \Delta P}{G}\left[\frac{f}{\left(f^{2}+r^{2}\right)^{3 / 2}}\right]
$$

(2)

\subsection{Yokoyama Model}

Yokoyama assumes the pressure source is sphere with unidirectional [13]. Below is some functions to find the horizontal (radial) replacement by yokoyama model: 
$U_{r}=-\frac{a^{2} p}{18 \mu}\left[\frac{6 F R}{\left(F^{2}+R^{2}\right)^{3 / 2}}-\frac{3\left\{F-\left(F^{2}+R^{2}\right)^{1 / 2}\right\}}{R\left(F^{2}+R^{2}\right)^{1 / 2}}\right]-\frac{a^{4} p}{126 \mu}\left[\frac{19 F R}{\left(F^{2}+R^{2}\right)^{3 / 2}}-\frac{2 R}{F\left(F^{2}+R^{2}\right)^{3 / 2}}+\frac{2}{F^{2}} \frac{F-\left(F^{2}+R^{2}\right)^{1 / 2}}{R\left(F^{2}+R^{2}\right)^{1 / 2}}\right]$

(3)

\subsection{Methods}

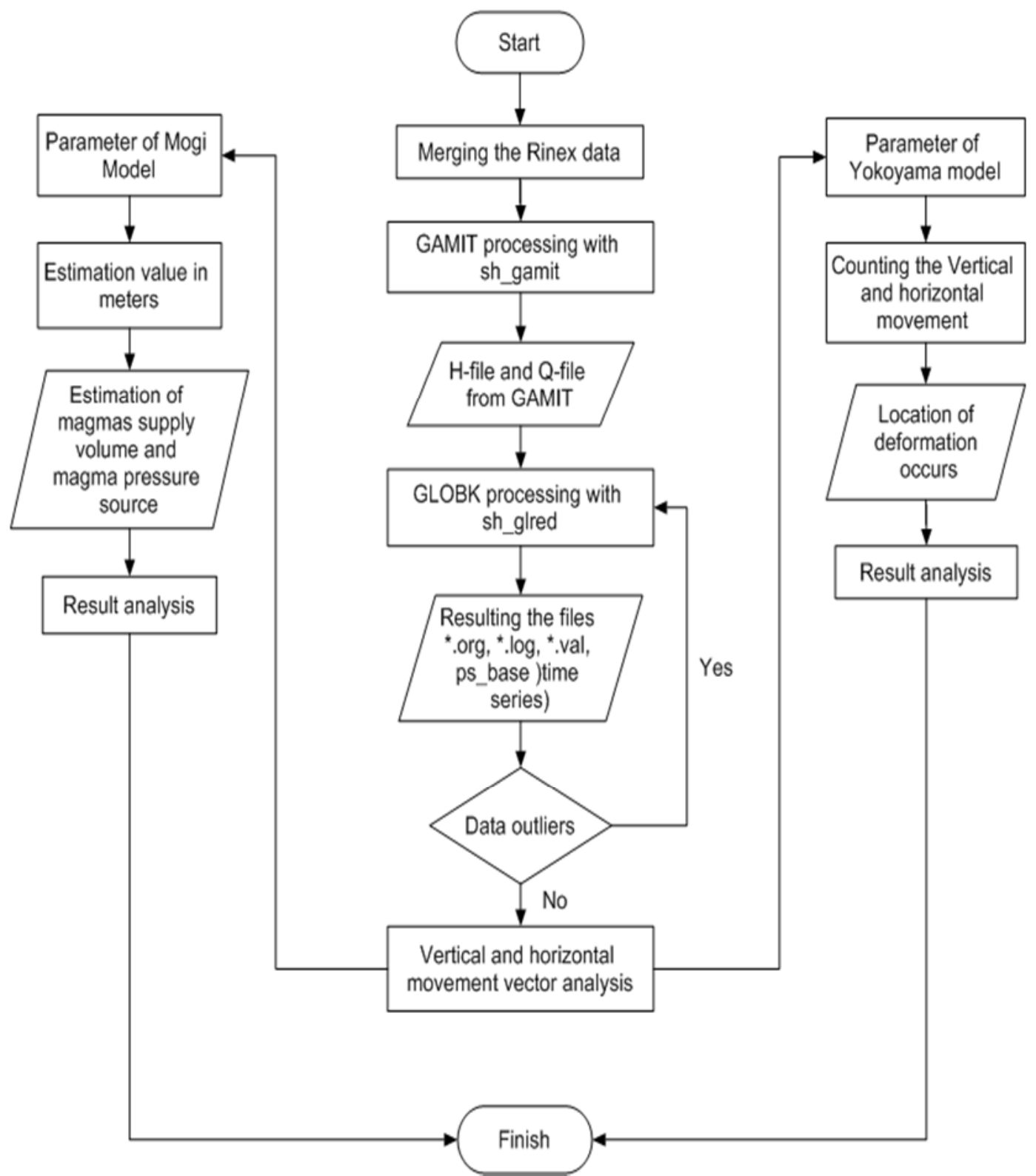


Fig.1. Flowchart of the research

GPS data were taken from 4 monitoring stations, 1 station is as the main point station (BPPTKG station) and the other 3 stations (GRWH, KLAT, DELS) sit around Merapi volcano as the monitoring stations. GPS data in Rinex format are recorded 24 times a day (1 data for each hour). GPS data were taken during 2009 - 2011. Qualitative analysis is done by analyzing the deformation based on the change of coordinate (degree) between the Merapi's crater and its monitoring stations (GRWH, KLAT, DELS). The quantitative analysis is done by Mogi and Yokoyama models.

GPS data processing uses GAMIT/GLOBK software, the geocentric and topocentric coordinate is out in GLOBK processing. Afterwards, the deformation is observed as time series so the position of GPS data movement can be known. The deformation of Merapi volcano can be specified from the change of coordinate between Merapi's crater and monitoring stations (GRWH, KLAT, DELS). The flowchart of this research can be seen in Fig.1.

\section{Results and Discussionss}

\subsection{GPS Data Analysis}

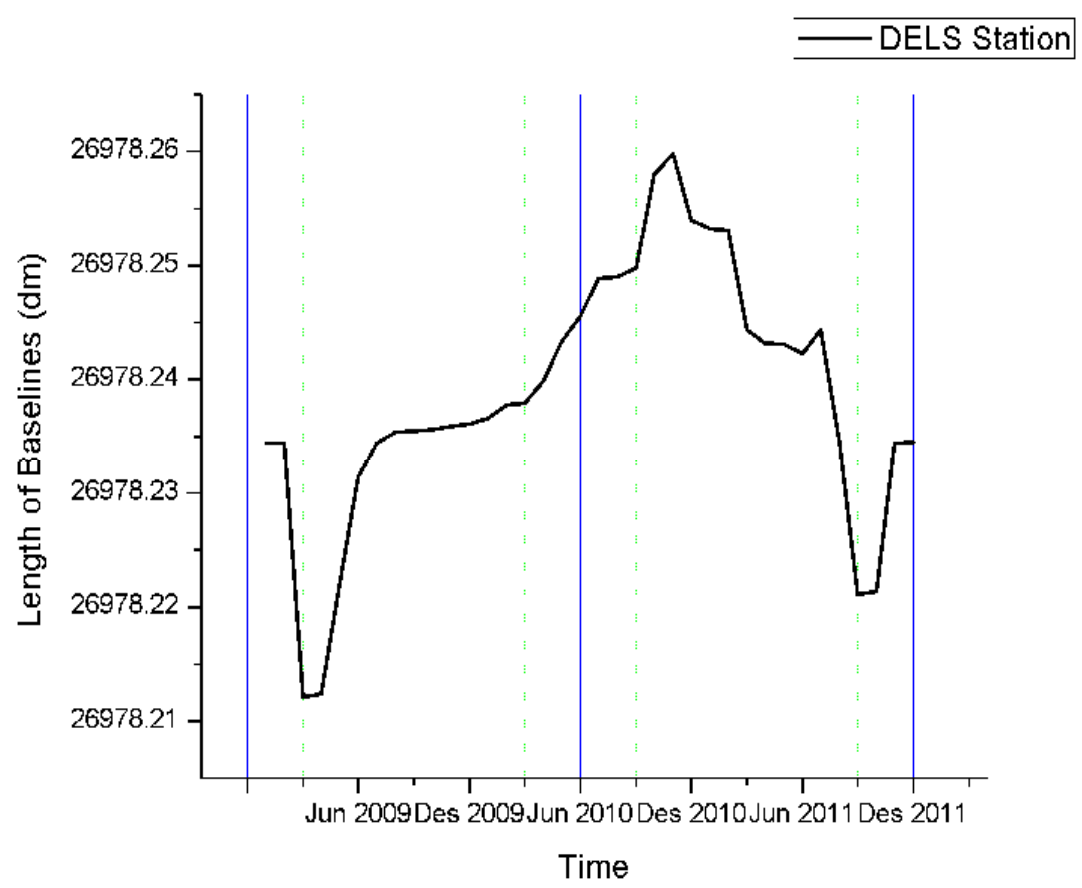

Fig.2. The change of baseline in DELS station 


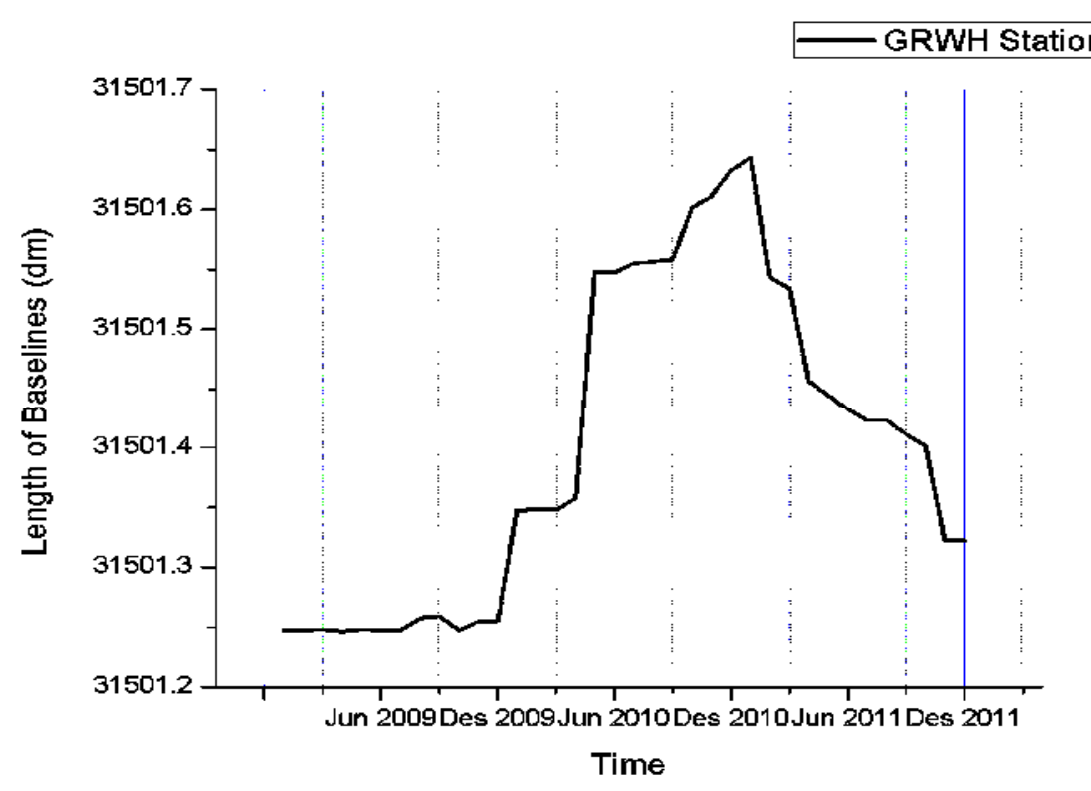

Fig.3. The change of baseline in GRWH station

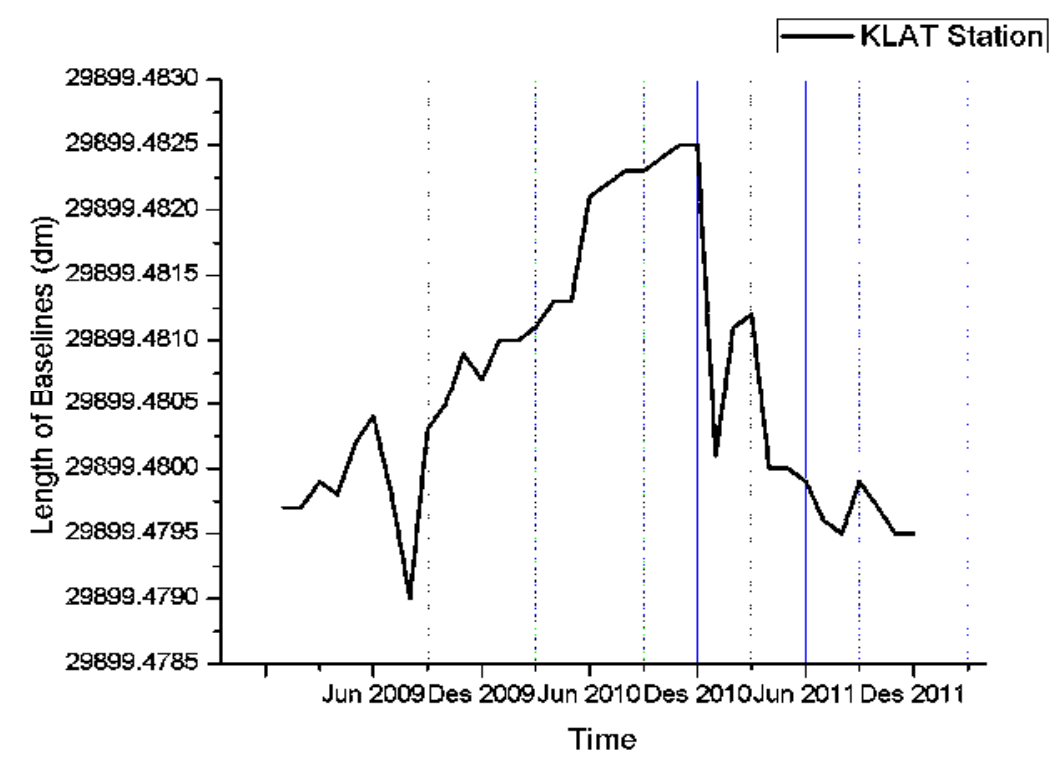

Fig.4. The change of baseline in KLAT station 
Monitoring of volcano activities can be known from inflation and deflation process that caused by pressure change inside the volcano. The changes process can be recorded from the length of baselines. Baseline is a distance between Volcano's crater and its monitoring stations. Besides, deformation activity can be known form the height of monitoring stations. If the changes are positive, it shows inflation process and if the change are negative, it shows deflation process [6].

Based on Fig 2, Fig 3, and Fig 4 above, it can be seen in around 2009-2010 there are some baselines lengthening. The distance between Merapi's crater and three monitoring stations are increasing continuously about +0.01 meters to +0.3 meters long. It means that volcanic activity in Merapi volcano is rising (inflation). It ends with a huge yet enduring eruption at the end of October 2010. After the eruption occurs, the volcanic activity has finally decreased (deflation). The distance between crater and three monitoring stations are shortened about -0.001 meters to -0.4 meters long.

Deformation is closely related to magma storage inside the volcano. Deformation is also caused by the volcanic activity change inside the volcano. If magma is moving from the bottom to the top of volcano, the surface of volcano is inflation and becomes bigger than before because a pressure beneath the surface. This inflation process causes the lengthening of baselines (distance between Merapi's crater and monitoring stations). If magma is moving from the top to the bottom of volcano, the surface of volcano is deflation and becomes smaller than before. This deflation process causes the shortening of baselines.

\subsection{Seismicity Data Analysis}

Seismicity data becomes an indicator to see the raising of volcanic activities toward the eruptions. Merapi Volcano's seismicity in 2009-2011 are indicated by some VTA, VTB, and guguran earthquakes. For example, during the eruption in October 2010, there are 4 volcanic earthquakes and followed with 2 guguran earthquakes. This shows that magma is moving and flowing up from magma pouch to the upper ground. The pressure of magma below the surface induces the volcanic and guguran earthquakes occur. The pressure of magma from inside the volcano induces the rocks fall down from the summit because of gravity effect.

Volcanic earthquakes can be used to determine the hypocenter of the earthquakes. $0-1.5$ $\mathrm{km}$ depth of earthquakes are called VTB (Shallow Volcanic-Tectonic) and then the $2.5-5 \mathrm{~km}$ depth of earthquakes are called VTA (Deep Volcanic-Tectonic). Below are the location of the hypocenter of earthquakes around Merapi Volcano [14].

Seismicity data are picked by using Seisgram $2 \mathrm{~K}$, inputted and processed by Hypoellips so the latitude, longitude, and the depth of hypocenter can be known. The result of the seismicity data processing are figured below: 


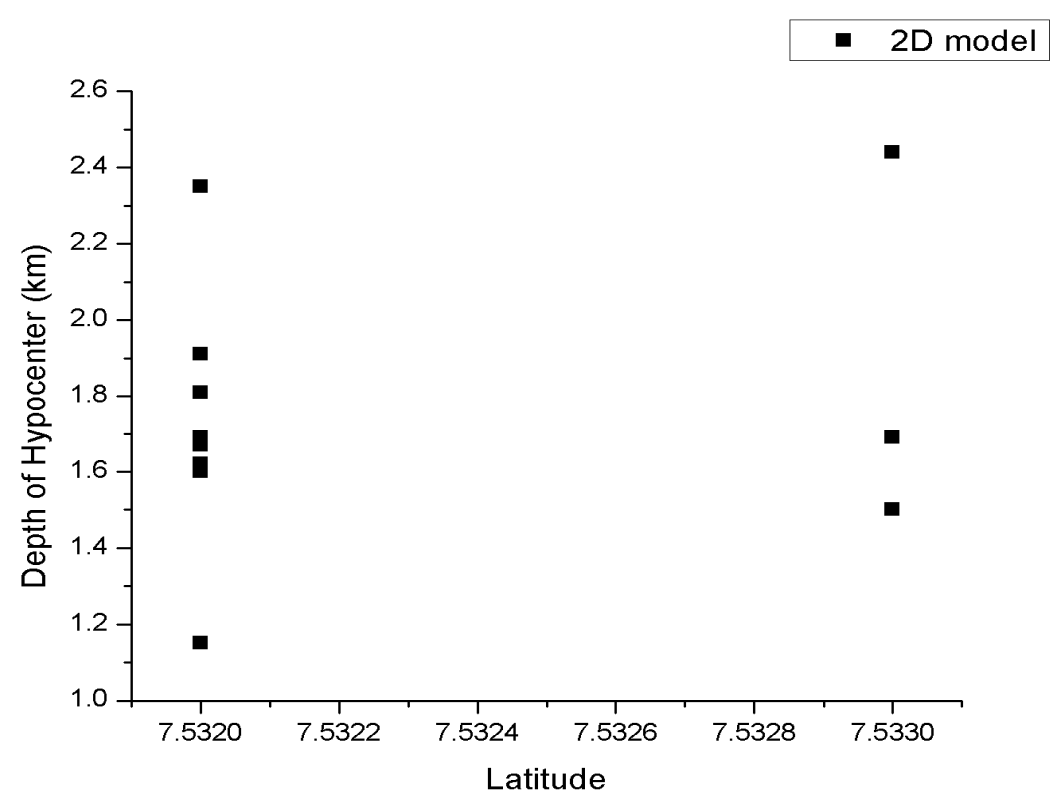

Fig.5. The depth of hypocenter based on its latitude

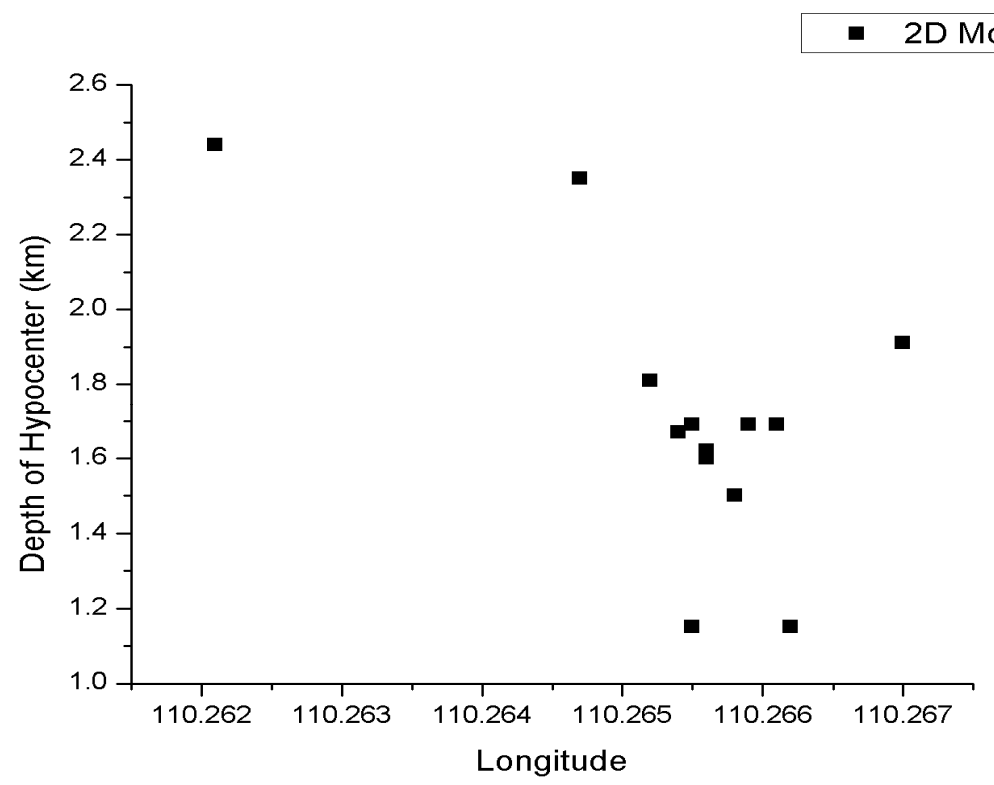

Fig.6. The depth of hypocenter based on its longitude 


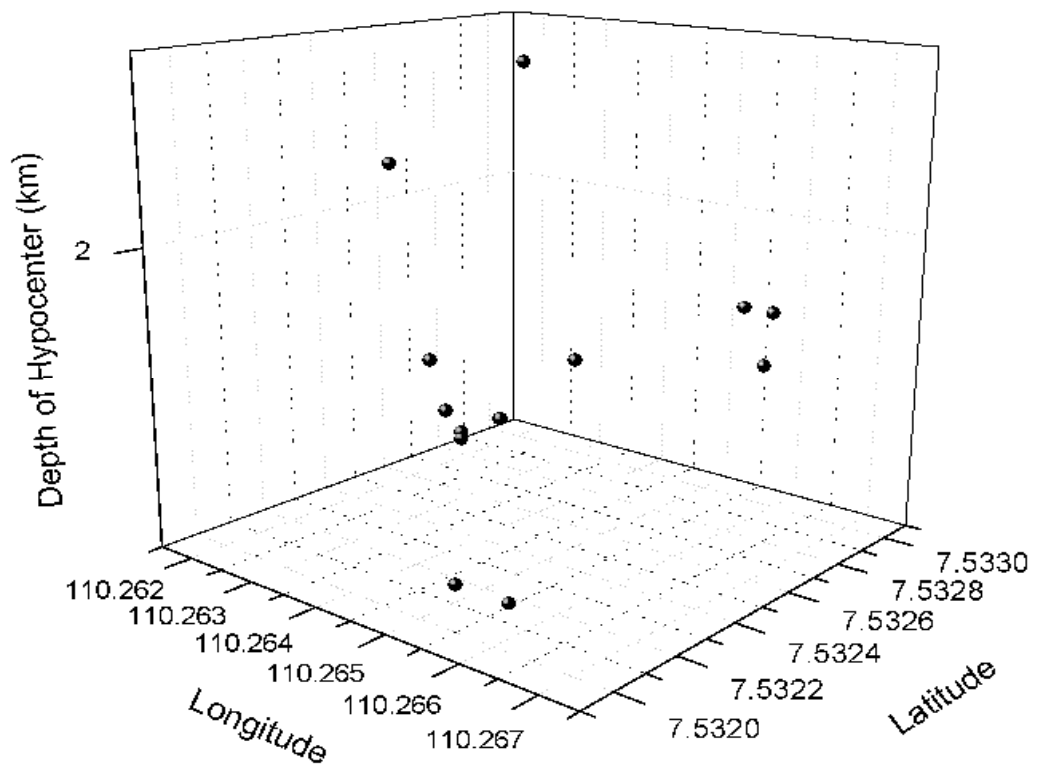

Fig.7. 3D model of the hypocenter's depth during eruption 2010

\subsection{The Movement Vector Analysis by Using Yokoyama Model}

Yokoyama assumes the pressure source is sphere with unidirectional. One of many ways to determine the deformations that occurs in the body of volcano is by knowing the pattern of the movement vector for each coordinate of GPS monitoring stations by using Yokoyama model. Activities in shallow pressure source deliver the recorded interaction in the surface of Merapi Volcano. It can be shown from its directions of movement vector.

The modelling process of deformation activity in Merapi Volcano shows the location of magma pressure source is in the Northwest of Merapi's summit and its depth is 2200 meters beneath the surface. See Fig 8: 


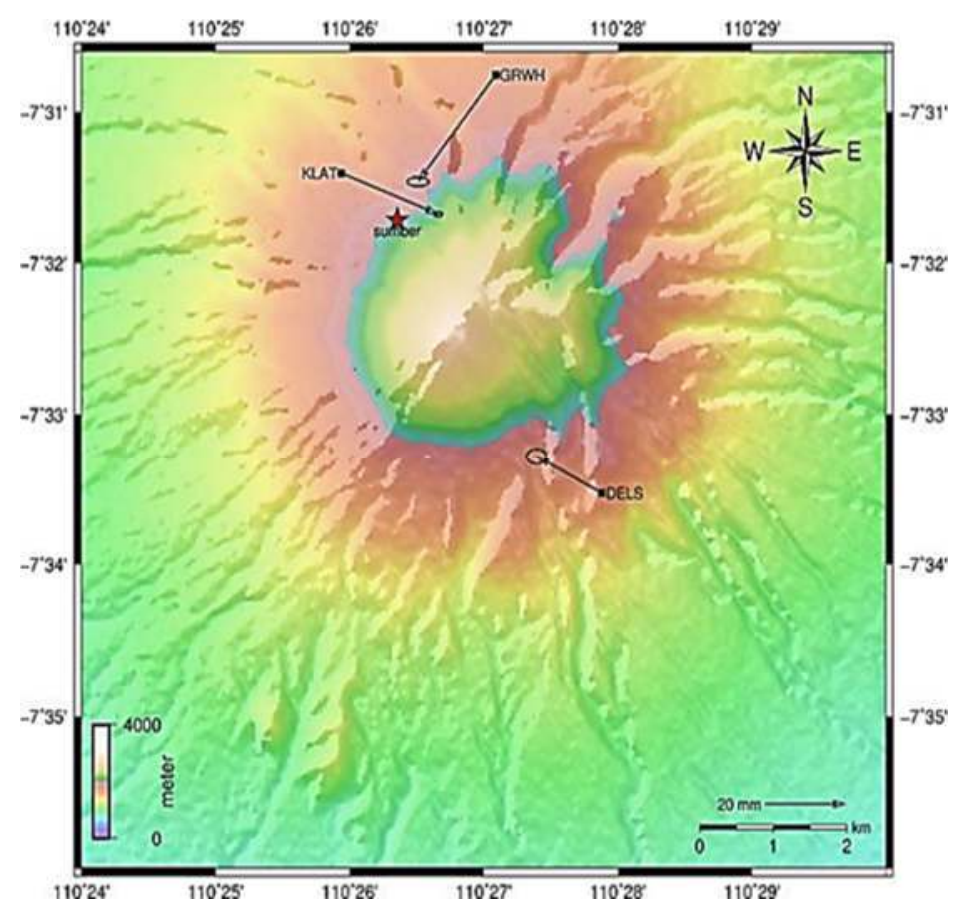

Fig.8. Directions of movement vector of Merapi Volcano

\subsection{Estimation of The Depth of Pressure Source by Using Mogi Model}

Pressure source or dilatation pressure source (Mogi Model) by Kiyoo Mogi [15] conclude that the geodetic measurement about the change of elevation and horizontal replacement closely related to the eruption (volcanic activity inside the volcano).

GPS data anomalies in 2009-2011 are -0.4 meters to +0.4 meters. These anomalies can be used to calculate and determine the location of magma pressure source and the magma supply volume below the surface of Merapi Volcano by using Mogi model. With assumptions that magma pressure source cause the volcano's surface change, either it inflation or deflation.

Based on qualitative analysis, every GPS graphs of DELS, GRWH, and KLAT stations show the deformation significantly. GPS data anomalies can be used to calculate the depth of magma pressure source and also the magma supply volume beneath the Merapi's surface.

Mogi model's calculation uses function (1) in section II. By inputting the parameters of Mogi Model (distance between crater and monitoring stations, data anomaly, poisson ratio, rigidity of mediums, and radius of magma pouch), the depth of pressure source can be known. 
Table 1. Mogi Model Parameters

\begin{tabular}{ccccc}
\hline $\begin{array}{c}\text { Data Anomaly } \\
\text { (meter) }\end{array}$ & $\begin{array}{c}\text { Radius of } \\
\text { Magma Pouch } \\
\text { (meter) }\end{array}$ & $\begin{array}{c}\text { Change of } \\
\text { Hydrostatic } \\
\text { Pressure (Pa) }\end{array}$ & $\begin{array}{c}\text { Rigidity of } \\
\text { Medium (Pa) }\end{array}$ & $\begin{array}{c}\text { The Depth of } \\
\text { Pressure Source } \\
\text { (meter) }\end{array}$ \\
\hline 0.000001 & 550 & $10^{5}$ & $2 \times 10^{10}$ & 2200 \\
\hline
\end{tabular}

Based on this research, the location of magma pressure source still sits inside magma pouch, even there are some shallow volcanic activities occur. Besides, inflation in the body of Merapi Volcano indicates that volcanic activities have pressed the volcano's body. Fig 8 has shown a point below the surface of Merapi Volcano. That point is the location of magma pressure source after eruption occurs, which is located in 2200 meters or $2.2 \mathrm{~km}$ relative below the surface.

Mogi Model's calculation shows that the depth of pressure source is 2200 meters or $2.2 \mathrm{~km}$ beneath the surface of Merapi Volcano. The depth of pressure source can be figured in 2D or 3D model by using Surfer 13 or Origin Pro 8.0. Below is the 3D models of Merapi volcano and the location of magma pressure source:

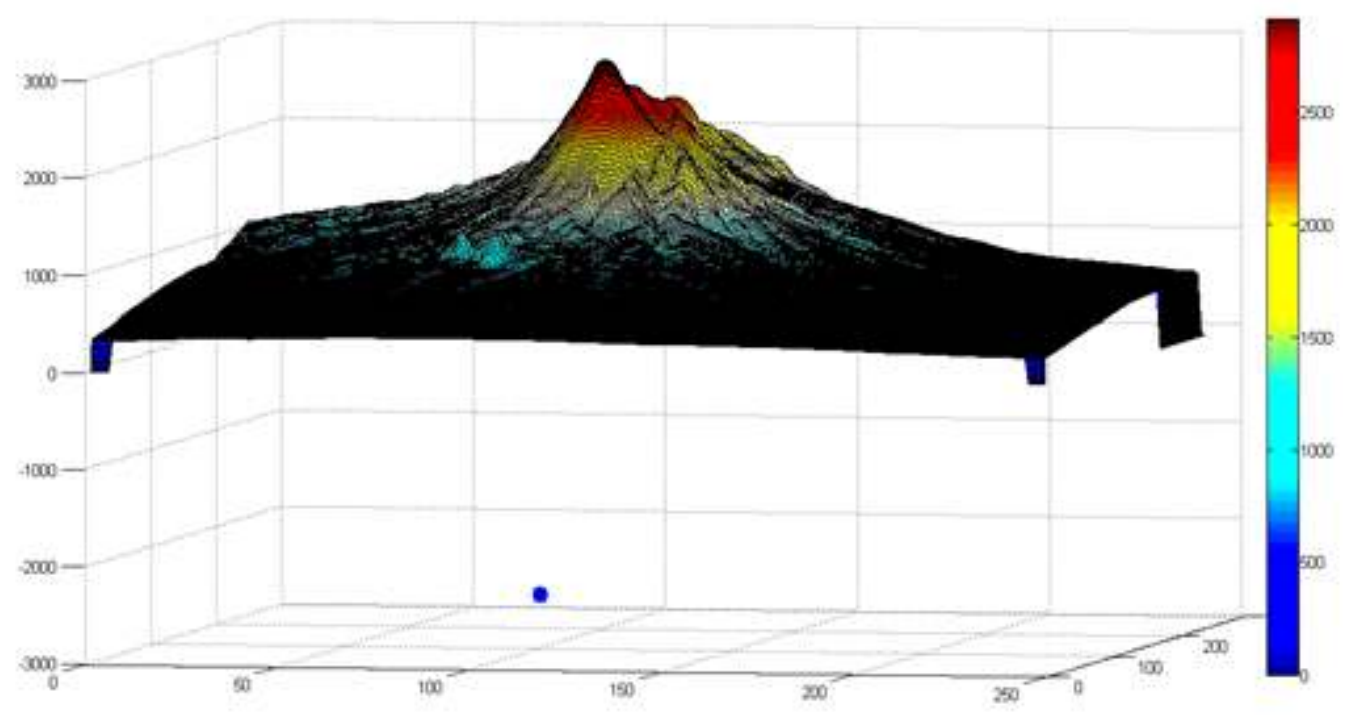

Fig.8. 3D model of Merapi Vocano and the location of magma pressure source

\subsection{Estimation of Magma Supply Volume}

The change of magma supply volume related to the change of hydrostatic pressure in any pressure source. Magma's density lean to be different with the mediums around them, so magma can flow up to the surface. The change of magma supply volume that's related to the change of hydrostatic pressure cause some deformations recorded in monitoring stations. Therefore, Mogi 
Model can be used to calculate the magma supply volume inside the volcano. Calculation of magma supply volume use this equation below [11]:

$$
\Delta V=4 \pi \frac{\left(f^{2}+r^{2}\right)^{5 / 2} \delta}{9 f r}
$$

Based on GPS data analysis, result in DELS and KLAT stations don't show the deformation during 2009-2011 significantly. So, the calculation of magma supply volume is using the result in GRWH station. Based on the equation above, Mogi model's calculations by using Microsoft Excel have shown that magma supply volume before eruption is 55 million. $\mathrm{m}^{3}$ and begin to decrease into 23 million. $\mathrm{m}^{3}$ after the eruption.

\section{Conclusions}

A month toward the eruption 2010, there is a baseline lengthening (inflation) between the crater and some Merapi Volcano's monitoring stations. The baseline lengthening is about +0.001 meters to +0.3 meters long. After the eruption, in the beginning of 2011 till the end of 2011, the baseline is shortened (deflation) about -0.0001 meters to -0.4 meters long.

Estimation of the depth of pressure source before eruption 2010 is $2.3 \mathrm{~km}$ and after eruption, it is decreasing into $2.1 \mathrm{~km}$. Estimation of magma supply volume before eruption 2010 is 55 million. $\mathrm{m}^{3}$ and after eruption, it is decreasing into 23 million. $\mathrm{m}^{3}$.

\section{References}

[1] US Geological Survey, "The 2010 Eruption of Merapi Volcano”, Journal of Vulcanology and Geothermal Research, vol. 261, no. 6, 2013.

[2] Katili. J.A. and S.S. Siswowidjojo, "Pemantauan Gunungapi di Filipina dan Indonesia", Ikatan Ahli Geologi Indonesia (IAGI). ISBN: 979-8126-05-6. 321 h + xii, 1994.

[3] Hasanuddin et al, "The Deformation of Bromo Volcano (Indonesia) as Detected by GPS Surveys Method”, Journal of Global Positioning System, vol. 3, no. 1-2, 2004.

[4] Beauducel, F. and Cornet, F., "Collection and Three-Dimensional Modelling of GPS and Tilt Data at Merapi Volcano-Java”, Journal of Geophysical Research, vol.104, no. B1, p. 725-736, 1999.

[5] Sari, S., "Sistem Pemantauan Gunungapi dan Bencana Geologi: Analisis Deformasi Gunung Kelut Berdasarkan Data Tilt Tahun 2006 sampai Februari 2007 Sebagai Studi Kasus", Purwokerto: Universitas Jendral soedirman Press, 2007.

[6] McGuire B., C.R.J. Kilburn. and J. Murray, "Monitoring Active Volcanoes", London: UCL Press Limited. 1995.

[7] Bemmelen V.R.W., "The Geology of Indonesia vol I-A", Printed Offices The Hague Martinus Nijhof, 1949.

[8] Balai Penyelidikan dan Pengembangan Teknologi Kebencanaan Geologi (BPPTKG). 2016. www.merapi.bgl.esdm.go.id/informasi. Accessed on 24th July 2018.

[9] Abidin, H.Z., "Survey dengan GPS", Jakarta:Pradnya Paramita, 2002.

[10] Hofmann-Wellenhof, B., H. Lichtenegger, and J. Collins, "Global Positioning System, Theory and Practice", Wien: Springer, 1994. 
[11] Dzurisin, D., "Volcano Deformation, Geodetic Monitoring Techniques. Checister: Springer, 2007.

[12] Kusumastuti, D.R., "Estimasi Kedalaman Sumber Tekanan dan Volume Suplai Magma Gunung Merapi berdasarkan Data Tiltmeter", Unpublished Thesis. Yogyakarta: Physics Department of Gadjah Mada University, 2014.

[13] Yokoyama, I., "Model for The Crustal Deformation Around Volcanoes". Journal of Physics of The Earth, Vol.19, no. 3, 1971

[14] Ratdomopurbo, A. and Poupinet, G., "An Overview of The Seismicity of Merapi Volcano (Java, Indonesia)", Journal of Volcano and Geothermal, vol. 100, no. 1-4, p. 193-214, 1995.

[15] Mogi, K., "Relation Between The Eruption of Various Volcanoes and The Deformation of The Ground Surface Around Them", Bulletin of Earthquake Research Institute, vol. 36, p. 99-134, 1958. 